\title{
KECEMASAN TERHADAP BERITA HOAX DITINJAU DARI STRATEGI EMOSI PADA MILLENNIAL MOM
}

\author{
Herwanto* \\ *Program Studi Psikologi, Universitas Negeri Jakarta \\ **Program Studi Psikologi, Universitas Negeri Jakarta
}

Sarah Febyani**

DOI: https://doi.org/10.21009/JPPP.041.03

\author{
Alamat Korespondensi: \\ herwanto@unj.ac.id
}

\begin{abstract}
Ease access to the internet makes hoax news spread easily in this time. Milennial mom which is a generation that followed by technological and social media development is very vulnerable in believe and anxious towards hoax. The causes of anxiety involve the ability of individual behavior maintain and emotion regulation. Therefore, emotion regulation strategies are required by millennial mom for not easily feels anxious towards hoax news. The purpose of this research is to see the different levels of anxiety about hoax news based on the emotion regulation strategies on millennial mom. The method of this research is quantitative. In this research, hypothesis testing was performed using Mann-Whitney U test. Based on calculations that has been done, it can be seen that the significance value is 0,002 which is less than the significance level ( $\alpha$ ) 0,05 and $Z$ count value is 3,131 which is more than Z table 1,96. This means that Ha is accepted and Ho is rejected. The conclusion of this research is there were significant differences in the levels of anxiety towards hoax news in millennial mom based on regulation emotion strategy, and emotion regulaion strategy cognitive reappraisal has a lower level of anxiety towards hoax news.
\end{abstract}

\section{Keywords}

anxiety, hoax, emotion, emotional regulation, reappraisal, suppression

\section{Pendahuluan}

Penggunaan internet belakangan ini menjadi hal yang sangat dibutuhkan oleh seluruh dunia termasuk Indonesia. Kemudahan mengakses internet membuat suatu informasi sangat mudah untuk didapatkan orang lain. Pengguna internet disarankan untuk berhati-hati dalam penggunaan internet, khususnya sosial media seperti facebook, twitter, whatsapp, dan sebagainya. Beberapa pengguna telah menyalahgunakan media sosial sebagai lahan penipuan dan menyebar kebohongan yang tidak dapat dipertanggungjawabkan kebenarannya. Berita bohong atau hoax yang tersebar melalui internet ini biasanya mengandung provokasi, informasi yang salah, SARA, pence- maran nama baik bahkan yang berifat menakutnakuti.

Menurut Milhorn (2007) usaha untuk menipu hingga membuat percaya bahwa sesuatu yang salah itu adalah benar disebut dengan "hoax". Menurut filologi Inggris Robert Nares, asal kata hoax berasal dari kata hocus yang artinya untuk menipu. Berita hoax yang tersebar luas di media sosial cukup meresahkan publik karena hal tersebut menimbulkan kecemasan bagi mereka. Ketika seseorang percaya pada informasi baru yang ia dapat dari individu lainnya, individu tersebut percaya bahwa mereka tidak akan memberikan suatu hal yang merugikan. Adanya hoax dalam interaksi melalui media sosial ini menunjukkan bahwa terdapat tindakan oleh 
pembuat atau penyebar berita yang memanfaatkan kepercayaan yang diberikan oleh korban penipuan dalam mempersepsikan suatu hal.

Direktorat Reskrimsus Polda Metro Jaya (www.kominfo.go.id) mengatakan bahwa perkembangan media sosial yang ada menjadi salah satu faktor penyebab semakin banyak penyebaran berita hoax. Reskrimsus mendeteksi adanya ribuan akun media sosial dan media online yang menyebarkan informasi hoax, provokasi hingga SARA. Generasi milenial merupakan generasi dengan diikuti perkembangan teknologi dan internet, sehingga sangat rentan dalam menerima dan membaca berita hoax. Terutama apabila hoaxtersebut memuat ancaman terhadap hal yang berhubungan dengan keseharian mereka.

Menurut American Psychological Association (APA), generasi milenial mengalami lebih banyak tekanan dan kurang mampu mengelolanya dari pada generasi lainnya. Lebih dari separuh dari mereka mengaku terbangun di malam hari selama bulan lalu karena stres. Tidak mengherankan, generasi milenial juga lebih cemas daripada orang Amerika yang lebih tua. APA melaporkan bahwa $12 \%$ generasi milenial memiliki gangguan kecemasan yang didiagnosis-hampir dua kali persentase generasi Baby Boomer, kelahiran tahun 1946 - 1964 (forbes.com).

Bensinger, DuPont and Associates (BDA) Morneau Shepell dalam Employee Assistance Program (EAP) menemukan bahwa generasi milenial memiliki tingkat kecemasan paling tinggi dibandingkan dengan generasi yang lain terutama pada wanita. Michael Snell dalam Sebagian besar kasus ini umumnya disebabkan oleh stress. Sejumlah penelitian terbaru menunjukkan bahwa generasi milenial menderita kecemasan pada tingkat yang jauh lebih tinggi daripada generasi yang mendahului mereka dan wanita hampir dua kali lebih mungkin menderita kecemasan dibandingkan pria. Menurut kajian literatur ilmiah yang ada, yang dilakukan oleh para peneliti di Cambridge University, juga menemukan bahwa kecemasan secara tidak proporsional memengaruhi orang-orang di bawah usia 35 tahun.

Pengguna internet khususnya generasimilenial perlu memahami apakah informasi yang diberikan berdampak baik bagi orang lain, bukan menyebabkan kemarahan, kebencian, dendam, atau permusuhan. Karena dengan adanya berita bohong yang bersifat negatif berupa provokasi, SARA, dan sebagainya dapat menimbulkan kecemasan serta emosi yang sulit untuk dikendalikan. Sebagai contoh kasus hoax di Brebes, Jawa Tengah. Seorang gelandangan yang mengalami gangguan jiwa menjadi bulan-bulanan warga karena tersebarnya berita yang mengatakan orang tersebut merupakan seorang penculik anak kecil yang sedang menyamar menjadi gelandangan dengan gangguan jiwa. Kemudian warga sekitar menghakimi orang tersebut dengan melakukan pengeroyokan fisik. Bahkan sejumlah warga daerah tersebut sempat menggantung dan mengarak orang tersebut keliling desa dengan posisi kepala korban menyentuh aspal dan tanah (http:// liputan6.com).

Berita negatif yang diterima oleh pengguna internet, dapat memperkuat atau mengubah persepsi dari pembacanya yang dapat mengubah jalan pikiran mereka. Hasil dari penelitian Szabo (2007) menunjukkan bahwa berita yang disiarkan atau disebarkan dapat menjadi pemicu peningkatan emosi negatif yang dimunculkan dalam bentuk kecemasan yang tinggi. Begitu pula dalam penelitian Harrel (2000) dalam Szabo (2007) yang melihat efek dari berita positif dan negatif dariberbagai suasana hati. Hasilnya menunjukkan bahwa ketika seseorang melihat berita yang berisi negatif dapat meningkatkan kecemasan secara signifikan dan memberikan pengaruh negatif dibandingkan orang yang melihat berita yang berisi positif.

Berita negatif yang tersebar di internet yang bersifat provokasi, menakut-nakuti dan ketidakjelasan sumber berita tersebut merupakan pencetus dari kecemasan penggunanya. Kecemasan sangat berkaitan dengan perasaan yang tidak pasti, tidak aman, serta menimbulkan perasaan tidak menyenangkan. Menurut Drajat (1995) kecemasan merupakan perasaan yang tidak menentu, panik, takut tanpa mengetahui sesuatu yang ditakutkan dan tidak dapat menghilangkan perasaan gelisah serta mencemaskan tersebut (Susanti, 2011). Sedangkan menurut Post (1978), kecemasan adalah kondis emosional yang tidak menyenangkan, yang ditandai oleh perasaanperasaan subjektif seperti ketegangan, ketakutan, kekhawatiran dan juga ditandai dengan aktifnya sistem syaraf pusat. Berdasarkan definisi-definisi tersebut dapat disimpulkan bahwa kecemasan 
adalah perasaan yang tidak menyenangkan yang diikuti dengan perasaan-perasaan subjektif yang negatif.

Kecemasan yang disebabkan oleh berita hoax diperkuat berdasarkan wawancara informal terhadap 6 subjek yang merupakan millennial mom, memiliki setidaknya satu media sosial yang aktif, dengan latar belakang pekerjaan yang berbeda. Dalam wawancara informal tersebut, terdapat lima dari enam ibu yang merasa khawatir, takut, dan waspada terhadap berita hoax yang bersifat negatif serta berhubungan dengan keamanan serta keselamatan pada anak. Kecemasan terhadap hoaxdapat dikatakan sebagai state anxiety karena terjadi ketika seseorang menerima stimulus berupa berita bohong. Spielberger (1972) mendefinisikan stateanxiety sebagai kecemasan yang muncul kapanpun seseorang mempersepsikan setiap stimulus atau situasi yang memiliki potensial membahayakan, gawat, atau mengancam baginya.

Berdasarkan definisi serta faktor-faktor kecemasan di atas, penyebab kecemasan umumnya mencakup pada kemampuan individu dalam pengaturan tingkah laku serta emosi yang baik. Oleh karena itu, untuk mengatasi kecemasan terhadap hoax diperlukan regulasi emosi yang baik sehingga millennial mom tidak mudah cemas ketika menerima berita hoax. Regulasi emosi adalah kemampuan yang dimiliki individu untuk menilai, mengatasi, mengelola dan mengungkapkan emosi yang tepat untuk mencapai keseimbangan emosional (Gross, 2007).

Regulasi emosi merupakan cara individudalam mengekspresikan emosi ke dalam ekspresi yang dapat mengkomunikasikan perasaan emosionalnya dengan cara yang baik serta dapat diterima secara sosial. Setiap individu dituntut untuk dapat mengekspresikan emosi secara sehat, adaptif dan dapat diterima oleh lingkungan. Keberhasilan mengungkapkan emosi secara adaptif ditentukan oleh kemampuan regulasi emosi yang memadai yang akan mengarahkan manusia untuk dapat mengatasi masalah-masalah emosi yang dialami sehingga dapat berperilaku adaptif dan terhindar dari perilaku maladaptif. Regulasi emosi merupakan strategi yang dilakukan untuk mempertahankan emosi yang seimbang. Hal tersebut sesuai dengan pengertian dari regulasi emosi yaitu strategi yang dilakukan secara sadar ataupun tidak sadar untuk mempertahankan, memperkuat atau mengurangi satu atau lebih aspek dari respon emosi yaitu pengalaman emosi dan perilaku. Seseorang yang memiliki regulasi emosi dapat mempertahankan atau meningkatkan emosi yang dirasakannya baik positif maupun negatif. Selain itu, seseorang juga dapat mengurangi emosinya baik positif maupun negatif (Gross, 2007).

Sejumlah penelitian telah memperlihatkan hubungan antara regulasi emosi dan kecemasan. Salah satunya adalah penelitian yang dilakukan oleh Mayangsari \& Ranakusuma (2014), mengenai hubungan regulasi emosi dan kecemasan yang dilakukan pada 311 petugas penyidik kepolisiandan pegawai negeri sipil. Dalam penelitiannya menyebutkan bahwa strategi regulasi emosi cognitive reappraisal memiliki hubungan yang signifikan dengan kecemasan sesaat (state anxiety) Kemudian penelitian yang dilakukan oleh Hoffman, dkk. (2009) mengenai strategi regulasi emosi suppression, reappraisal dan acceptance sebagai cara mengatasi kecemasan. Penelitian tersebut dilakukan terhadap 202 relawan yang diminta memberikan pidato secara spontan di depan kamera yang kemudian diminta untuk meregulasikan emosinya sesuai dengan kelompoknya. Hasilnya adalah kelompok suppression menunjukkan kecemasan yang lebih tinggi dari awal dibandingkan kelompok Reappraisal and Acceptance. Kemudian reappraisal dinilai lebih efektif untuk memoderasi perasaan subjektif kecemasan daripada suppression dan acceptance.

Berdasarkan fakta-fakta yang ada sekarang ini, penelitian mengenai regulasi emosi dan kecemasan terhadap berita hoax menjadi penting untuk dilakukan, mengingat belum ada judul penelitian tersebut di Indonesia serta untuk mengetahui lebih lanjut hubungan dari kedua variabel tersebut. Dalam penelitian ini, akan dibahas mengenai perbedaan tingkat kecemasan terhadap strategi regulasi emosi cognitivereappraisal dan expressive suppression yang akan berfokus pada Millenial Mom yaitu ibu yang dibesarkan pada era berkembangnya teknologi dan internet. Pemilihan subjek tersebut ditentukan berdasarkan penelitian sebelumnya yang mengatakan bahwa wanita pada generasi milenial lebih cemas dibandingkan lakilaki, serta banyaknya pemberitaan hoax yang berhubungan dengan kejahatan pada anak di Indonesia. 
Penelitian ini juga dianggap penting dilakukan pada variabel regulasi emosi dan kecemasan pembaca berita hoax pada millennial mom karena dengan tingginya angka penyebaran hoax di Indonesia dapat memunculkan permasalahanpermasalahan dalam emosi yang akan menyebabkan permasalahan lain bagi pembacanya yang akan merugikan diri sendiri maupun lingkungan sosialnya.

\section{Metode}

Tipe penelitian yang digunakan dalam penelitian ini adalah penelitian kuantitatif. Dalam penelitian ini teknik sampling yang digunakan adalah purposive sampling. Sampel yang digunakan dalam penelitian ini adalah wali murid SDN Jatiwaringin IX. Karakteristik sampel dalam penelitian ini adalah sebagai berikut: Ibu dengan kelahiran tahun 1978-1994, memiliki minimal 1 orang anak, memiliki setidaknya 1 media sosial, aktif menggunakan media sosial. SDN Jatiwaringin IX dipilih karena tempat tersebut mudah diakses bagi para subjek penelitian karena subjek mengantarkan anaknya sekolah di sekolah tersebut. Kemudian pihak sekolah memberikan kemudahan kepada peneliti dan peserta dengan fasilitas meja dan kursi yang ada, serta belum pernah dilaksanakan kegiatan serupa dengan tema yang sama ditempat tersebut.

Sebelum penelitian ini dilaksanakan, dilakukan validasi wacana untuk menentukan berita hoax yang akan digunakan untuk mengukurkecemasan, kemudian berita yang digunakan adalah "Penjualan Organ Tubuh Anak, Dikirim ke China" karena berita tersebut menghasilkan kecemasan yang paling tinggi diantara 9 berita lain yang diberikan.

Pengumpulan data dilakukan dengan menggunakan kuesioner. Kuesioner dalampenelitian ini merupakan skala psikologi. Penelitian ini menggunakan dua buah skala psikologi untukmengukur kedua variabel yang digunakan. Kecemasan diukur menggunakan instrumentkecemasan State Trait Anxiety Inventory (STAI) form Y-1 yang dikembangkan oleh Spielberger (1983). Instrumen kecemasan yang digunakan dalam penelitian ini hanya form state anxiety karena hanya ingin mengukur kecemasan sesaatresponden. Kemudian regulasi emosi diukur menggunakan instrumen regulasi emosi Emotion Regulation Questionnaire (ERQ) milik James J.Gross (2003) yang telah diterjemahkan oleh Muthia A. (2013).

\section{Hasil Penelitian dan Diskusi}

Penelitian ini dilakukan pada 17 responden. Skor regulasi emosi yang diperoleh dalam penelitian ini dikategorikan menjadi duakategori berdasarkan strategi regulasi emosi responden yaitu cognitive reappraisal dan expressive suppression. Penentuan kategorisasi ini dilakukan berdasarkan perbandingan Z-score pada kedua dimensi regulasi emosi cognitive reappraisaldan expressive suppression. Sehingga didapatkan 9 responden cenderung menggunakan strategi regulasi emosi cognitive reappraisal dan 8 responden cenderung menggunakan strategi regulasi emosi expressive suppression.

Uji hipotesis dalam penelitian ini menggunakan Mann-Whitney U Test. Untuk pengujian hipotesis dilakukan perhitungan dengan menggunakan SPSS versi 24.0 dan didapatkan hasil sebagai berikut:

a. Nilai signifikansi sebesar 0,002 yang berarti lebih kecil dari taraf signifikansi $(\alpha) 0,05$. Hal tersebut menunjukkan probabilitas dalam penelitian ini sebesar $0,02 \%$.

b. Nilai Z hitung sebesar 3,131 yang lebih besar dari $\mathrm{Z}$ tabel sebesar 1,96 sehingga Ha diterima dan Ho ditolak.

c. $\mathrm{Z}$ hitung dalam penelitian ini bersifat negatif, yaitu $-3,131$ yang berarti mean kelompok cognitive reappraisal lebih rendah dibandingkan mean kelompok expressive suppression. Hal ini menunjukkan bahwa padapenelitian ini terdapat perbedaan yang signifikan pada tingkat kecemasan terhadap berita hoax berdasarkan strategi regulasiemosi pada millennial mom.

Hasil yang diperoleh dari analisis data berdasarkan hasil perhitungan mann-whitney $u$ testyang telah dilakukan pada 17 responden, menunjukkan 9 responden menggunakan strategi regulasi emosi cognitive reappraisal dan 8 responden menggunakan strategi regulasi emosi expressive suppression. Kemudian hasil penelitian juga menunjukkan bahwa berita hoax dapat menimbulkan kecemasan pada millennial mom. Selanjutnya berdasarkan hasil pengujian hipotesis dengan SPSS 24.0, diperoleh nilai signifikansi sebesar 0,002 
yang berarti lebih kecil dari tarafsignifikansi $(\alpha)$ 0,05 dan nilai nilai $Z$ hitung sebesar 3,131 yang lebih besar dari $Z$ tabel sebesar 1,96 sehingga $\mathrm{Ha}$ diterima dan Ho ditolak. $Z$ hitung dalam penelitian ini bersifat negatif, yang berartimean kelompok cognitive reappraisal lebih rendah dibandingkan mean kelompok expressive suppression. Hal ini menunjukkan bahwa pada penelitian ini terdapat perbedaan yang signifikan pada tingkat kecemasan terhadap berita hoax berdasarkan strategi regulasi emosi pada millennialmom. Kemudian kelompok expressive suppression memiliki tingkat kecemasan yang lebih tinggi dibandingkan kelompok cognitive reappraisal.

Hasil penelitian tersebut menunjukkan hasil yang searah dengan asumsi peneliti yang mengatakan bahwa terdapat perbedaan yang signifikan pada tingkat kecemasan terhadap berita hoax berdasarkan strategi regulasi emosi pada millennial mom. Hasil penelitian ini juga sejalan dengan penelitian yang dilakukan oleh Gross \& John (2003) yang menunjukkan bahwa individu yang cenderung menggunakan regulasi emosi cognitive reappraisal akan cenderung merasakan dan mengekspresikan emosi positif, serta memiliki hubungan interpersonal yang lebih baik dan hangat dengan orang lain. Kemudian hal tersebut juga sesuai dengan hasil penelitian sebelumnya dari Hoffmann, et al. (2009) bahwa reappraisal lebih efektif untuk memoderasi perasaan subjektif kecemasan daripada suppression atau acceptance.

Menurut Gross (2003) penggunaan regulasi emosi suppression biasanya efektif dalam menurunkan ekspresi tingkah laku dari emosi negatif seperti marah, tetapi suppression tidak membantu dalam menurunkan emosi negatif, akibatnya penurunan emosi negatif berlangsungsecara lambat dan terakumulasi menjadi emosi yang tidak terselesaikan. Karena itu dibutuhkan lebih banyak sumber kognitif untuk memulihkan emosi. Berdasarkan pendapat tersebut hasil dalam penelitian ini sesuai karena kecemasan pada kelompok cognitive reappraisal lebih dapat mengatasi kecemasan dibandingkan kelompok expressive suppression.

\section{Kesimpulan}

Hasil pengujian hipotesis berdasarkan hasil perhitungan independent sample t-test menunjukkan bahwa terdapat perbedaan yang signifikan pada kecemasan berita hoax berdasarkan strategi regulasi emosi pada millennial mom. Kemudian strategi regulasi emosi yang lebih baik dalam mengatasi kecemasan berita hoax pada millennial mom adalah regulasi emosi cognitive reappraisal.

\section{Daftar Pustaka}

Alwisol. (2009). Psikologi Kepribadian (edisi revisi). Malang: Umm Press.

Aprisandityas \& Elfida (2012). Hubungan antara Regulasi Emosi dengan Kecemasan pada Ibu Hamil. Jurnal Psikologi, 8(2).

Beaton, C. (2016). 8 Habits That Make Millennials Stressed, Anxious, and Unproductive. Forbes. Diakses 18 Maret, 2017, diambil dari https://www.forbes.com.

Bolton, R. N., Parasuraman, A., Hoefnagels, A., Migchels, N., Kabadayi, S., Gruber, T., Loureiro, Y. K., Solnet, D. (2013). Understanding Gen $\mathrm{Y}$ and Their Use of Social Media: A Review and Research Agenda. Journal of Service Management, 24(3), 245-267.

Creswell, J. W. (2010). Research Design, Pendekatan Kuantitatif, Kualitatif, dan Mixed. Yogyakarta: Pustaka Belajar.

Feist J., \& Feist, G. J. (2010). Theoriest of Personality. New York: McGraw-Hill,Inc.

Gross, J. J. (2007). Handbook of Emotion Regulation. New York: The Guillford Press.

Gross, J. J., Oliver, P. J. (2002). Emotion Regulation: Affective, Cognitive, and Social Consequences. Psychophysiology, 39, 281-291.

Gross, J. J., Oliver, P. J. (2003). Individual Differences in Two Emotion Regulation Processes: Implications for Affect, Relationship, and Well-Being. Journal of Personality and Social Psychology, 85(2), 348-362. 
Herwanto

Sarah Febyani

Gross, J. J., Oliver, P. J. (2004). Healthy and Unhealthy Emotion Regulation: Personality Processes, Individual Differences, and Life Span Development. Journal of Personality, 72(6), 1301-1330.

Gross, J. J. \& Thompson, R. A. (2007). Emotion Regulation: Conceptual Foundation. Handbook of Emotion Regulation, edited by. James J. Gross. New York: Guilford Publications.

Hoffmann, et al. (2009). How to Handle Anxiety: The Effects of Reappraisal, Acceptance, and Suppression Strategies on Anxious Arousal. Behaviour Research and Therapy, 47, 389-394.

Julian, L. J. (2011). Measures of anxiety. Arthritis Care \& Research, 63(11):467-472. DOI 10.1002/acr.20561

Mayangsari \& Ranakusuma. (2014). Hubungan Regulasi Emosi dan Kecemasan pada Petugas Penyidik Polri dan Penyidik PNS. Jurnal Psikogenesis, (3)1.

Nevid, J. S, dkk. (2005). Psikologi Abnormal (5th ed.). Jakarta: Erlangga.

Nisfianoor, M., Kartika, Y. (2004). Hubungan antara Regulasi Emosi dan Penerimaan Diri Kelompok Teman Sebaya Remaja. Jurnal Psikologi, (2)2.

Putnam, K. M., \& Silk, K. R. (2005). Emotion Dysregulation and the Development of Borderline Personality Disorder. Development and Psychopathology, 17: 899-925.

Rossi \& Pourtois. (2011). Transient state Dependent Fluctuations in Anxiety Measured Using STAI, POMS, PANAS or VAS: a comparative review. Anxiety, Stress \& Coping: An International Journal, 25(6), 603-64.
Kecemasan Terhadap Berita Hoax Ditinjau dari Strategi Emosi pada Millennial Mom

Safaria, T. (2007). Regulasi Emosi, Need of Achievement, dan Self-Esteem antara Perempuan dan Laki-Laki. Diakses 8 Maret, 2017, dari http://nofransekasaputra. blogspot.co.id

Spielberger, C. (1972). Current Trends in Theory and Research on Anxiety. In C.D. Spielberger (Ed.), Anxiety: Current Trends in Theory and Research, 2.

Spielberger, C. D . (2004). State Trait Anxiety Inventory STAI. Palo Alto, CA: Consulting Psychogists Press.

Spielberger, C., \& Reheiser, E. (2009). Assesment of Emotion: Anxiety, Anger, Depression, and Curiosity. Applied Psychology: Health and Well-being, (3)1, 271-302. doi: 10. 1111/j.1758-0854.2009.01017.x.

Sumintono, B., \& Widhiarso, W. (2014). Aplikasi Model Rasch untuk Penelitian Ilmu-Ilmu Sosial. Cimahi: Trim Komunikata Publishing House.

Suryaratri, R., \& Rangkuti, A. (2013). Statistika Deskriptif dalam Psikologi dan Pendidikan. Jakarta: FIP - UNJ.

Susanti \& Faridah. (2011). Efektivitas Musik Klasik dalam Menurunkan Kecemasan Matematika (Math Anxiety) pada Siswa Kelas XI. Humanitas, VIII (2).

Szabo, A. \& Hopkinson, K. L. (2007). Negative Psychological Effects of Watching the News in the Television: Relaxation or Another Intervention May Be Needed to Buffer Them!. International Journal of Behavioral Medicine, 14(2), 57-62. 